International Journal of Life Sciences
Available online at http://sciencescholar.us/journal/index.php/ijls
Vol. 2 No. 1, April 2018, pages: $12 \sim 20$
e-ISSN: 2550-6986, p-ISSN: 2550-6994
http://dx.doi.org/10.29332/ijls.v2n1.75

\title{
Sustainable Development Seen from Environmental Training in University Linkage
}

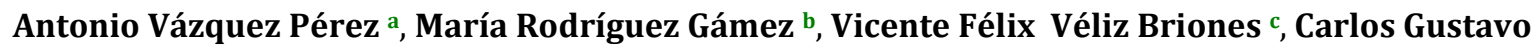 \\ Villacreses Viteri ${ }^{d}$, Lucio Alfredo Valarezo Molina e
}

Article history: Received 17 July 2017, Accepted in revised form 21 January 2018, Approved 1 February 2018, Available online 7 February 2018

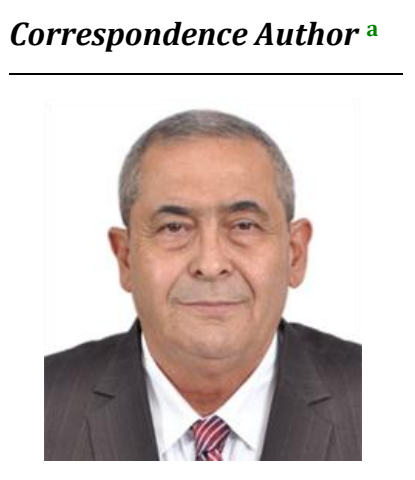

Keywords

Environmental crisis;

Environmental education;

Resilience;

Sustainable development;

University linkage;

\begin{abstract}
The environmental complexity arises in the world as an effect of the forms of knowledge, but it is not only a relation of knowledge. This concept emerges from the world interpreted by science as an objective, fragmented and specialized knowledge. Therefore, complexity and systems theory arise at the same time as the environmental crisis is manifested. The research work starts from an idea linked to the formation of current and future generations to achieve sustainability from the direct link of educational centers with society, an experience that is addressed from the university, as a sure way to influence the achievement of sustainable development. It offers a developing vision of the role that the student and the university institution should play in terms of sustainability inspired by a logical model of community bonding, where students figure as central actors in the action process, learning and serving the same community time that they demand from others what they can and should do in the interests of sustainable development.
\end{abstract}

e-ISSN : 2550-6986, p-ISSN : 2550-6994@ Copyright 2018. The Author. SS Journals Published by Universidad Técnica de Manabí. This is an open-access article under the CC BY-SA 4.0 license (https://creativecommons.org/licenses/by-sa/4.0/) All rights reserved.

\section{Contents}

Abstract

1. Introduction 13

2. Research Method 13

a MsC. Faculty of Sciences, Mathematics, Physics and Chemistry, Universidad Técnica de Manabí, Portoviejo, Ecuador

b Ph.D. Professor, Faculty of Sciences, Mathematics, Physics and Chemistry, Universidad Técnica de Manabí, Portoviejo, Ecuador

c Ph.D. Rector of the Universidad Técnica de Manabí, Portoviejo, Ecuador

d Ms.C. Head, Dean and Associate Professor, Faculty of Sciences, Mathematics, Physics and Chemistry, Universidad Técnica de Manabí, Portoviejo, Ecuador.

e Professor, Faculty of Sciences, Mathematics, Physics and Chemistry, Universidad Técnica de Manabí, Portoviejo, Ecuador 


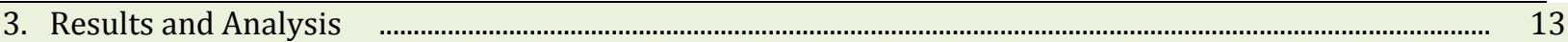

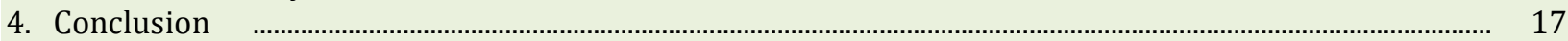

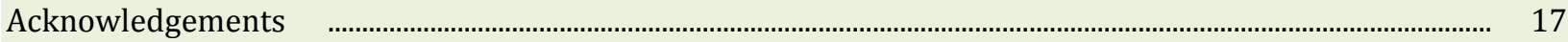

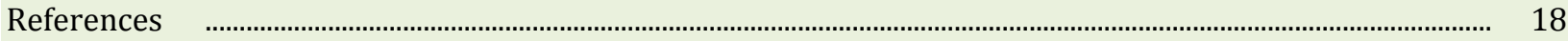

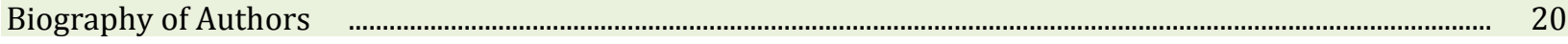

\section{Introduction}

Complexity as an epistemological paradigm of postmodernity leads to deep reflection on the very origins of the human condition, the whys of its actions, the prospecting of what is to come and the innumerable interactions between what we are and can become as a species and as a society. This way of analyzing the world is nothing else than the possibility of unraveling the deep roots and the extended branches of the tree called the history of humanity, which becomes a true forest when it is reflected in and from the knowledge necessary for the education of the present and future [1].

Making a brief reflection on those knowledge according to the paradigm of complexity and the great changes. We face in the present are fundamental to educate and educate environmentally in the future, whose great challenges include the peaceful coexistence of human beings, the care and preservation of other living beings, the harmonious relationship with the environment, empathy, tolerance, otherness and solidarity among other challenges we need to face in order not to disappear as a species.

The environmental complexity does not simply emerge from the generativity of nature that emanates from the real world. It develops from inert matter to the knowledge of the world; it is not the reflection of nature over nature, of life over life, of knowledge about knowledge, even in the metaphorical senses of that reflection that makes the real vibrate with the force of thought and word. The evolution of nature generates something radically new that emerges from nature. The emergence of language and the symbolic order inaugurates, within this evolutionary process, an indissoluble novelty in an ontological monism. The difference between the real and the symbolic, between nature and culture, which founds the human adventure: the meaning of the things, the consciousness of the world, the knowledge of the real [2].

The environmental complexity arises in the world as an effect of the forms of knowledge, but it is not only a relation of knowledge. This concept emerges from the world interpreted by science as an objective, fragmented and specialized knowledge. Therefore, complexity and systems theory arise at the same time as the environmental crisis is manifested. Likewise, the environmental complexity refers to the strategies of appropriation of the world and nature through the power relations that have been inscribed in the dominant forms of knowledge [3].

\section{Research Method}

The deductive method was used with the objective of carefully observing the historical evolution of environmental education before the emergence of the concept of sustainability and after it arose, which has made it possible to formulate the conclusions of the work by approaching the truth in interest. Of the environmental training function. The research was also based on the inductive method that allowed starting from particular premises to establish the general conclusions of the work. For all this, a literature review of the literature specialized in international environmental training was carried out.

\section{Results and Analysis}

\subsection{Differences between environmental education and education for sustainable development}

It is difficult to determine exactly when the term environmental education was used for the first time. One possibility is the National Conference on Environmental Education held in 1968 in New Jersey. At the end of the 1960s, several terms were used, including education for environmental management, education for the use of resources and education for environmental quality, to describe education focused on humans and the environment. However, environmental education is the term that has been most frequently used [4].

The International Union for the Conservation of Nature (IUCN) proposed in 1970. The following definition of Environmental Education: "It is the process of recognizing values and clarifying concepts to create necessary skills and attitudes, tending to understand and appreciate the mutual relationship between Man, his culture, and the surrounding biophysical environment Environmental education also includes the

Pérez, A., Gámez, M., Briones, V., Viteri, C., \& Molina, L. (2018). Sustainable Development Seen from Environmental Training in University Linkage. International Journal Of Life Sciences (IJLS), 2(1), 12-20. 
practice of making decisions and formulating a code of behavior regarding issues that concern environmental quality [5].

Environmental education can be defined as a continuous process in which individuals and the community become aware of their environment and acquire the values, skills and will to enable them to act in the resolution of current and future problems of the environment [6].

Certain aspects should be highlighted from this definition because they are precisely those that constitute the essence of environmental education: It is a continuous process. The emphasis is placed on the conscience, that is to say, that although logically it must be based on the knowledge of reality, it should never be confused with informing. It is not simply a matter of developing skills, but it must be complemented by a review of the scale of values and a strengthening of the will. It contemplates the principle of inter and transgenerational equity. And, finally, it is action-oriented (it is not passive) and decision-making (it is not merely critical) [7].

From its beginnings, environmental education emerged as a field education or nature studies, and for many years it occupied a little relevant part of the curriculum. On the other hand, it was not considered in pedagogical terms either. The growing awareness of the problem of sustainability significantly influenced environmental education, making it more complex and demonstrating its links with the social, economic, cultural and technological problems of the communities. The problem was, then, to give it a pedagogical vision, in addition to the mere praxis to achieve a critical mass of population sensitive to environmental problems. Today it is not only important to transmit to the students some environmental knowledge but to educate them in the framework of sustainability, promote the change of their behaviors and motivate them to assume personal and community responsibilities related to the environment [3].

Environmental education is key to understanding the existing relationships between natural and social systems, as well as to get a clearer perception of the importance of sociocultural factors in the genesis of environmental problems. In this line, it should promote the acquisition of awareness, values, and behaviors that favor the effective participation of the population in the decision-making process. Environmental education understood as such can and should be a strategic factor that influences the established development model to reorient it towards sustainability and equity [4].

At the World Summit of the United Nations Environment and Development Program in Rio de Janeiro (1992), on education, the Treaty of Environmental Education for Sustainable Societies and Global Responsibility was signed. At the meeting, a new term for environmental education emerged. With a new denomination that is considered more adjusted in comparison with others that were emerging at the time within the educational-environmental field: environmental education for Sustainable Development (proposed as an alternative to commitment between environmental education and education for sustainable development); education for sustainability (avoiding the appeal to development and its association with neoliberal environmentalism); formulated more as currents within an environmental education characterized by its theoretical and methodological plurality, with the idea of subverting the whole field [3].

When the new concept is analyzed in depth. It can be verified that it is about the representation in the educational field, of the controversy between environmentalism (the approaches of the environmental crisis that understand. It can be solved within the framework of the liberal market society or neo-liberal) and environmentalism (the approaches that demand a radical change in the model of society as a premise to address the environmental crisis and the development crisis), so it can be assumed that behind education for sustainable development, There is an ideological project clearly oriented to a liberal and market resolution of the double crisis, the ecological and the social, the two sides of the same coin. It is the only thing that explains the attempt to convince us that education for sustainable development exceeds environmental education [3].

However, it can be seen that the richness of the subject goes beyond what has been discussed so far and that within environmental education there are other visions, other alternatives, other paradigms, more critical and consistent with an equally sustainable, but also emancipatory, construction. Equitable and oriented towards social justice of the present and the future of humanity.

\subsection{Critical posture in environmental education}

The critical position in Environmental Education brings a feeling of dynamism and vitality to the subject, without which the students would not feel the necessary motivation needs that differentiate the 
environmental issue from other specifically sustainable themes where the relationship with the community is necessary.

The true environmental education starts from the permanent exercise and the adoption of a critical position, which allows questioning the objective reality from a creative vision and the adoption of new patterns of behavior in function of the protection of the natural resources and the environmental conditions of the planet.

The sense of criticality gives environmental education the characteristics of a subject that breaks with the inertia of the study center and the need to appeal to a dynamic pedagogy is felt as the teaching-learning process based on a set of knowledge linked to concepts, skills, and attitudes. The articulates vertebrally to all the matters and that does not die when leaving the educational establishment; that is part of the integral formation, conscious or unconscious, of the social subject, inside and outside the academy, in one or another subject, speaking with a teacher, a companion or a family member [6].

\subsection{The concept of active citizenship in a service-learning project in environmental education}

Active citizenship refers to the participation of individuals in life and public affairs. It can take place at the local, national or international level. It refers to citizens who are aware of their belonging to a local and global community and are actively involved in community life discussing their problems, promoting and supporting changes and improvements or confronting unwanted changes [7]. Active citizenship promotes solidarity, community and the social part of the neighborhood where it is emphasized in the group instead of the person. An active citizen is informed and uses the information to serve for or against, committing to the situation instead of just observing and commenting on it [8].

The linking of the exercise of citizenship with the pedagogical modality of service-learning demonstrates the advances that are experienced in the concepts of active citizenship, which involves the formation of a series of complex skills that are acquired and strengthened when they are put into play, the relations of environmental pedagogy [9]. The ideas to propose the application of the concept of active citizenship in a service-learning project in environmental education. It is aligned to the link with the effectively participatory citizenship, clearing the realm of fiction to work on a latent reality, where students can take care of society as a whole and use their experiences and knowledge of objective reality.

Figure 1 shows a logical model, where the students' relationship with society can help environmental training based on objective reality, where the behavior is not the same in all environments, so the results differ. From one site to another, the real and diverse is that, this training from the level and site that is, will contribute to reducing what we now call climate change, which is the accelerated process that is taking place on the planet, where anthropic action of man in various social activities, is causing the deterioration of the space where community activities are carried out. The agilest way to mitigate it is by linking the students of the different educational levels, to develop the linking processes oriented to the real needs of the environments where the education centers are located and to go from an idealistic stage to the materialization of the solution of environmental problems from an educational position.

The University plays an educational role not only for students enrolled in careers but also for students in schools in environments close to the home of study. Today agreements are made between other universities where the UTM play the role of central within the other universities [10].

Pérez, A., Gámez, M., Briones, V., Viteri, C., \& Molina, L. (2018). Sustainable Development Seen from Environmental Training in University Linkage. International Journal Of Life Sciences (IJLS), 2(1), 12-20. 


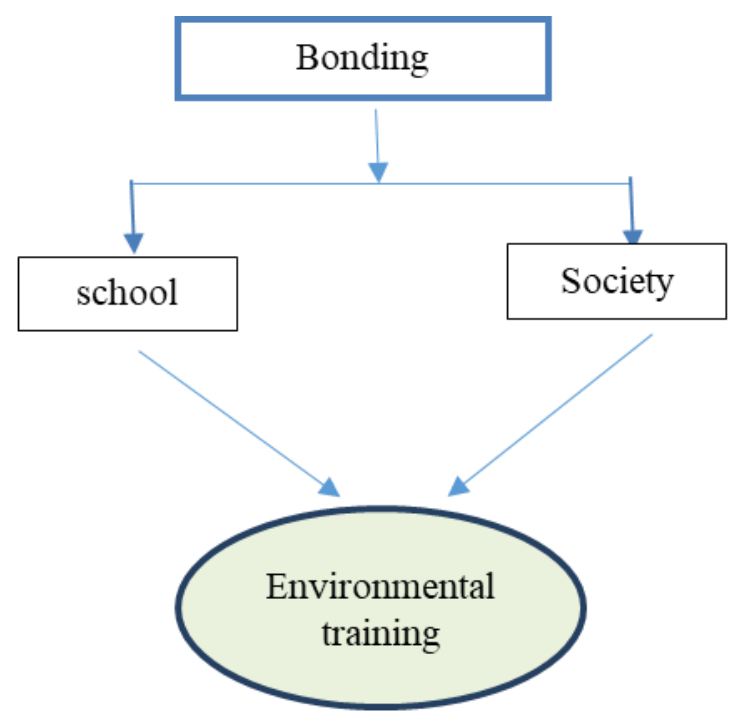

Students learn and serve the community, explore and discover their own capabilities and strengths, and from them assume responsibility for what they can and should do for the environment, in addition to demanding what others can and should do. Start living as active, participative and supportive citizens not only in the speeches, but in the real life of the community.

Figure 1. Model of student linkage for environmental training

\subsection{Resilience in a service-learning project in environmental education}

Some authors [11] consider that taking into account the social characteristics that exist in a university center. The study of resilience plays a key role. Since, it seeks to facilitate that all students fully develop their potential, enrich their lives and prevent dysfunctions that put resilience at stake in the student environment, which due to its characteristics is subject to constant changes. Resilience can be understood conceptually from different points of view, in psychology. It is understood by the ability of people to overcome periods of emotional pain and adverse situations. In sociology it refers to the ability of social groups to overcome adverse results, reconstructing their internal links. In order to make their homeostasis prevail (It is a form of dynamic equilibrium made possible by a network of systems of feedback control that constitute the mechanisms of self-regulation of living beings, has traditionally been applied in biology but, given the fact that not only the biological is capable of complying with this definition, other sciences and techniques have also adopted this term) collective, so that they do not fail in their synergy [12].

In ecology, resilience is related to the capacity of communities and ecosystems to absorb disturbances without significantly altering their structure and functionality, and can return to its original state once the disturbance has ceased. In environmental pedagogy, resilience is associated with the ability of a person to do things well despite adverse conditions, has emerged as an alternative that allows us to glimpse hope in situations that we commonly associate with only a cluster of deficiencies [13]. The concept of resilience (or faculty of recovery) involves two components: resilience against destruction, that is, the ability to protect one's integrity against distorting pressures; and the ability to build positive life behaviors despite difficult circumstances.

The concept of resilience in a service-learning project in environmental education can be applied, fostering the stimulation and development of the resilient capacity of people and social groups. In order to achieve a coherent and adequate relationship between the satisfaction of needs human resources and the possibilities of the environmental component of being able to meet these expectations. Resilience is a consubstantial capacity to environmental pedagogy for the development of service-learning projects in its 
two aspects since solidarity actions are closely linked to the ability to protect the integrity of people facing deforming pressures, together with the construction of positive life behaviors despite difficult situations

\section{Conclusion}

The work allows us to appreciate environmental training as a dynamic process of service-learning focused on sustainability, inspired by a novel training process that arises from the academy but does not remain in it, projecting its action and results towards the community, linking the academic knowledge proactively with the experience and popular traditions. As a result of the research, a simple action model focused on community work is offered. It is based on logical modeling of action where students learn and serve the community, explore and discover their potential and from them assume a leading role in defense of the environment.

\section{Acknowledgements}

We would also like to thank I.W. Suryasa as an advisor as well as editor in chief of IJCU, IJMRA, SKIREC, Euro Asia as well as ScienceScholar who has reviewed and approved this study to be published.

Pérez, A., Gámez, M., Briones, V., Viteri, C., \& Molina, L. (2018). Sustainable Development Seen from Environmental Training in University Linkage. International Journal Of Life Sciences (IJLS), 2(1), 12-20. 


\section{References}

1. Niño, A. C. M. (2012). La complejidad de la educación ambiental: Una mirada desde los siete saberes necesarios para la educación del futuro de Morin. Revista de Didáctica Ambiental, (11), 1-9.

View in (Google Scholar)

2. Leff, E. (2007). Complejidad, racionalidad ambiental y diálogo de saberes\&58; hacia una pedagogía ambiental. Desenvolvimento e meio ambiente, 16(unknown), 11-19.

View in (Google Scholar)

3. Michaud, M. (1855). Historia de las cruzadas. Librería española.

View in (Google Scholar)

4. Mancipe Navarrete, J. A., Garcia Villamil, S. S., Correa Bautista, J. E., Meneses-Echávez, J. F., González-Jiménez, E., \& Schmidt-RioValle, J. (2015). Efectividad de las intervenciones educativas realizadas en América Latina para la prevención del sobrepeso y obesidad infantil en niños escolares de 6 a 17 años: una revisión sistemática. Nutricion hospitalaria, 31(1).

View in (Google Scholar)

5. Martínez Castillo, R. (2010). La importancia de la educación ambiental ante la problemática actual. Revista Electrónica Educare, 14(1).

View in (Google Scholar)

6. Pérez, A. V., Perero, G. A., \& Gámez, M. R. (2016). LA EDUCACIÓN SUPERIOR Y LA CRISIS AMBIENTAL. RECUS. Revista Electrónica Cooperación Universidad Sociedad. ISSN 2528-8075, 1(1), 21-30.

View in (Google Scholar)

7. Castañeda, J. A. P. (2013). La "reinvención de la escuela" en la Bogotá Humana. Magazín Aula Urbana, (91), 3-5.

View in (Google Scholar)

8. López, T. R. A., López, Z. R. A., \& Chartuni, J. A. L. diagrama de la Asignatura. View in (Google Scholar)

9. Pintado, H. María J, Vitón, S. Belén, and Duran, Diana. (2015). La ciudadanía activa. Segundo curso. Módulo I. Aspectos pedagógicos de la Educación Ambiental Integrada al Aprendizaje-Servicio, 2015. View in (Google)

10.Pérez, A. V., Briones, V. V., Viteri, C. G. V., \& Gámez, M. R. (2017). Iberoamerica in Network, GIS \& TIC. International Journal of Social Sciences and Humanities (IJSSH), 1(3), 108-117.

View in (Google Scholar)

11. Meza, A. K. T., Aguayo, M. D. Z., Cevallos, M. G. O., \& Zambrano, P. F. R. (2018). Estimation of Resilience in University Students. International Research Journal of Management, IT and Social Sciences (IRJMIS), 5(1), 1624.

View in (Google Scholar)

12. Joya Espejo, K. A., \& Santa Pachón, E. E. (2017). Formulación de un plan de negocio para la puesta en marcha de una fundación en pro del apoyo a mujeres que padecen cáncer de mama en Bogotá.

View in (Google Scholar) 
13. Jurado, W. C. C., Pérez, A. V. P., Quiroz, A. M. V., \& Gámez, M. R. (2017). Environmental Impact On Electrical Networks Near The Manabita Litoral. International Journal of Life Sciences (IJLS), 1(2), 18-27.

View in (Google Scholar)

14. Jain, P., Jain, A., Singhai, R., \& Jain, S. (2017). Effect of Biodegradation and Non Degradable Substances in Environment. International Journal of Life Sciences (IJLS), 1(1), 58-64.

View in (Google Scholar)

15.Suryani, S. A. M. P., \& Arya, I. W. (2017). Improving the Quality of Tilapia (Oreochromis niloticus) With consumption measures Leaf Extract Neem (Azadirachta indica A. Juss) as Antiparasitic. International Journal of Life Sciences (IJLS), 1(3), 28-37.

View in (Google Scholar)

16. Ogu, G. I., \& Orjiakor, P. I. (2017). Microbiological and Nutritional Qualities of Fermented Melon Seed Shells. International Journal of Life Sciences (IJLS), 1(2), 1-9.

View in (Google Scholar)

17. Singh, D. (2017). Leaf Phenology of Cassia Sieberiana L. in KSUSTA Campus of Kebbi State, Nigeria. International Journal of Life Sciences (IJLS), 1(1), 1-8.

View in (Google Scholar)

18. Sutapa, I. K., Sutapa, I. N., \& Susila, I. N. D. (2017). Implementation of Active Rest in Participatory Ergonomics Decrease Workload and Women Musculoskeletal Complaints of Parking in Mall Ramayana Denpasar. International Journal of Life Sciences (IJLS), 1(2), 48-54.

View in (Google Scholar)

19. Arcentales, G. A. T., Lucas, M. A. P., Guerrero, J. A. C., \& Gordín, R. G. (2017). Evaluation for the Reduction of NH3 Contamination Risks. International Journal of Life Sciences (IJLS), 1(2), 10-17.

View in (Google Scholar)

20. Saxena, A. (2017). The Impact of Nutrition on the Overall Quality of Life Adolescent Girls are Living Across the City of Kota. International Journal of Life Sciences (IJLS), 1(1), 40-48.

View in (Google Scholar)

21. Alcivar, M. S. G., Pérez, A. V., Gilert, B. I. C., \& Gámez, M. R. (2017). Zeolite in Wastewater Decontamination as a Local Development Solution. International Journal of Life Sciences (IJLS), 1(3), 1-13.

View in (Google Scholar)

22. Sulistiawati, N. P. A., Kartini, L., \& Yuliartini, M. S. (2017). Identification of Development Phases and Changes Shoots Flowering Orange Siam Plants. International Journal of Life Sciences (IJLS), 1(2), 28-38.

View in (Google Scholar)

23. Delgado, G. R. E., Meza, A. K. T., Chávez, S. A. R., \& Murillo, G. S. A. (2018). Demands of People with Disabilities and Empowerment of Resilient Strategies. International Research Journal of Management, IT and Social Sciences (IRJMIS), 5(1), 45-54.

View in (Google Scholar)

Pérez, A., Gámez, M., Briones, V., Viteri, C., \& Molina, L. (2018). Sustainable Development Seen from Environmental Training in University Linkage. International Journal Of Life Sciences (IJLS), 2(1), 12-20. doi:10.29332/ijls.v2n1.75 


\section{Biography of Authors}

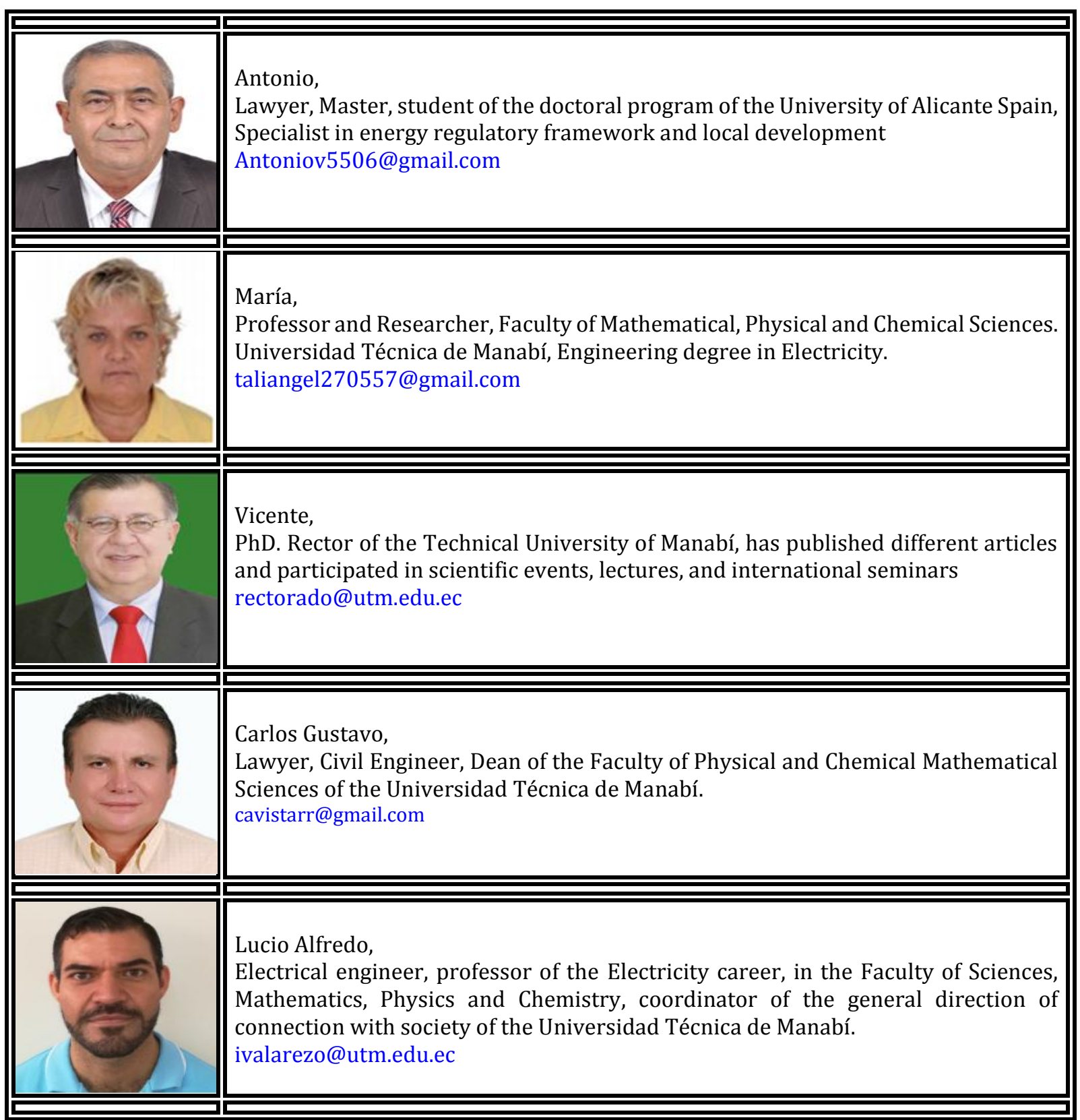

